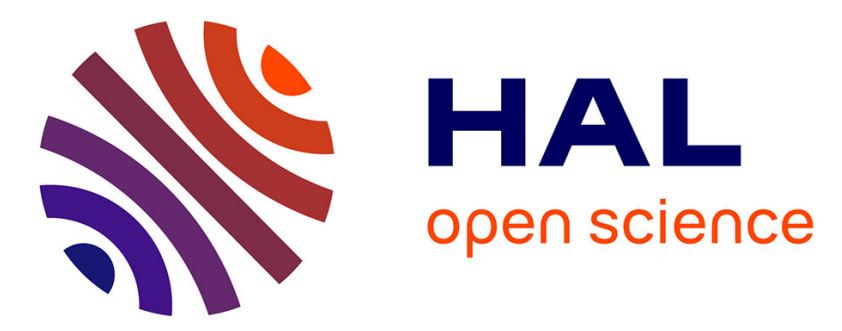

\title{
The Half Moon Photography Workshop and Camerawork: catalysts in the British photographic landscape (1972-1985) \\ Mathilde Bertrand
}

\section{- To cite this version:}

Mathilde Bertrand. The Half Moon Photography Workshop and Camerawork: catalysts in the British photographic landscape (1972-1985). Photography and Culture, In press. hal-01715445

\author{
HAL Id: hal-01715445 \\ https://hal.science/hal-01715445
}

Submitted on 27 Feb 2018

HAL is a multi-disciplinary open access archive for the deposit and dissemination of scientific research documents, whether they are published or not. The documents may come from teaching and research institutions in France or abroad, or from public or private research centers.
L'archive ouverte pluridisciplinaire HAL, est destinée au dépôt et à la diffusion de documents scientifiques de niveau recherche, publiés ou non, émanant des établissements d'enseignement et de recherche français ou étrangers, des laboratoires publics ou privés. 


\title{
The Half Moon Photography Workshop and Camerawork: catalysts in the British photographic landscape (1972-1985)
}

\author{
Mathilde Bertrand
}

English Studies Department, Université Bordeaux-Montaigne, Bordeaux, France.

UFR Lettres et Langues, Université Bordeaux-Montaigne, Esplanade des Antilles, F33607

Pessac Cedex. mbertrand@u-bordeaux-montaigne.fr

\section{Introduction}

In the 1960s, outlets for professional photography in Britain were limited to commercial, fashion and editorial photography published in the illustrated press, a very dynamic sector at the time. However, institutional recognition for photography as an art form was scant. Hardly any spaces showed photographs old and new; support for practicing photographers did not exist; few curators commissioned and exhibited photographic images; museums showed little interest in collecting photographs; and courses in photographic education were in their infancy (McWilliams 2009). As photographer and editor Bill Jay lamented, "the institutional foundations of photography in Britain were inert, inept and apathetic"(Jay 2004). ${ }^{1}$ However, photographic practices and discourses on the medium evolved rapidly from the end of the 1960s.

Within a decade, photography's contexts of production, circulation and reception in Britain were radically transformed. The period stretching from $1967^{2}$ to the early 1980 s represents a turning point in the history of British photography ${ }^{3}$, as photographers, art historians, gallery

\footnotetext{
${ }^{1}$ Bill Jay was editor of Creative Camera between 1965 and 1969, then of Album (February 1970 - February 1971).

${ }^{2}$ When the new Royal Charter of the Arts Council of Great Britain provided for the creation of a sub-committee for photography.

${ }^{3}$ Jorge Ribalta uses the expression "the long 1970s" to refer to this transformative period. (Ribalta 2015)
} 
administrators, curators, critics and officers in the Arts Council and the Regional Arts Associations multiplied initiatives and allowed photography to expand in an unprecedented manner. This expansion was visible, on the one hand, in terms of the development of photographic practices, as new structures of support enabled professional photographers to explore the visual possibilities of the medium more freely, to exhibit their work and find an audience.

On the other hand, the growth of theoretical analyses on the semiotics of photography opened new critical perspectives. Analyses on the social uses of photography, on its place in the sphere of the media or within the context of institutional structures, meant that the medium could no longer be considered as a neutral tool of representation. This evolution cannot be decoupled from the growing influence of British Cultural Studies, which turned academic attention to popular cultural forms and practices outside of established cultural canons. Photography, as a versatile image, practice and object intervening in a broad range of social contexts, did not escape scrutiny.

One organization founded in the East End in 1972 played a determinant role in this important shift in both practice and theory. Half Moon Gallery, which took the name Half Moon Photography Workshop in October 1975 and Camerawork in spring 1981(Read 2017), was a photographers-led initiative whose activities revolved around a gallery space with on-site and touring exhibitions, the publication of the specialized magazine Camerawork ${ }^{4}$, and an educational program combining workshops and seminars with the provision of darkrooms open to all. At a moment when photography was gaining more recognition as a cultural form from art historians and critics, Half Moon Photography Workshop opened an essential forum for attentive scrutiny on the photographic image and its uses in the media, the gallery, the

\footnotetext{
${ }^{4} 32$ issues were published between February 1976 and summer 1985.
} 
family, the schoolroom or in community politics. The group's consistent focus on these questions contributed to politicizing discourses on photographic practices and theory. Yet the detailed history of the Half Moon Photography Workshop and the very important critical debates that animated it in the late 1970s and 1980s have been overlooked. Jessica Evans's edited volume of selected Camerawork articles leaves aside crucial contributions by key members such as Jo Spence, and does not discuss what is at stake in the organization's statement of aims, an extremely rich text in itself (Evans 1997). However, recent academic and curatorial interest in politically committed photographic practices and alternative organizations in the 1970s has shed light on the central role played by the small but influential East End collective and on its links with 1930s collective forms of photographic practice such as the Workers' Photo and Film Movement (Edwards, 2017; Ribalta 2015; Wilson 2015). Thanks to the availability of archival material in the care of two London organizations ${ }^{5}$, the legacy of Half Moon Photography Workshop as a critical discursive space for photography is being rediscovered. Building on these sources and perspectives, this paper presents a detailed history of the organization, investigating the contexts of its creation, the formulation of its agenda, its major contributions and the evolution of the group. The early years of the group until the turn of the 1980s are given particular attention: this micro-historical perspective captures a moment in Britain's social and political history characterized by the emergence of radical grassroots initiatives of which the organization was but one manifestation. Drawing on interviews with actors involved in the life of the organization, the paper examines Half Moon Photography Workshop's independent political stance in the context of 1970s oppositional culture and argues that it acted as a catalyst in the expansion and politicization of the British photographic scene.

\footnotetext{
${ }^{5}$ At the Photography and the Archive Research Centre at the University of the Arts and at Four Corners Films. The Archives of the Arts Council and the Jo Spence Memorial Library: Terry Dennett Collection (Birkbeck University) also hold material relating to the Half Moon Photography Workshop.
} 


\section{From Half Moon Gallery to Half Moon Photography Workshop}

The early years of Half Moon Gallery were driven by its founders' youthful energy and innovative ideas. Their genuine passion for documentary photography and photojournalism, and, as will be developed later, an openness to alternative approaches to the medium and a confidence in what it could achieve politically, shaped the organization's vision and sustained its ambitious project. The idea of setting up photographic exhibitions in London's East End was the brainchild of American photographer Wendy Ewald. Half Moon Gallery started in 1972 as a small exhibition space in the foyer of a pocket theatre (and former synagogue) Half Moon Theatre, of which Ewald's partner was a member (figure 1). ${ }^{6}$ The gallery operated with very modest means and from cramped and damp office rooms. Ewald mobilized her network in order to gather financial support for the activities she wanted to develop, such as workshops on photography for the local community (Ewald 2006). ${ }^{7}$ It soon attracted young, non-established British photographers seeking to present their work, at a time when such spaces were non-existent. Half Moon Gallery offered an unpretentious yet practical and convivial environment (figure 2). ${ }^{8}$

The organization appeared at a moment when Britain counted only two other photographic galleries: the Photographers' Gallery, created in 1971 in London and directed by Sue Davies, ${ }^{9}$ exhibited more established photographers; Impressions Gallery in York, founded by Val

\footnotetext{
${ }^{6}$ Located in 27 Alie Street, London E1, the theatre took its name from nearby Half Moon Passage. (Ewald 2006)

${ }^{7}$ London' East End has a long multicultural history (characterized by the settlement of people from diverse religious and ethnic minorities) and radical history around Chartism, trade unionism, feminism and anti-fascism.

${ }^{8}$ Nick Hedges recalls showing his photographic series on factory work in 1978. "We were all very impoverished then. There was no money to spend on galleries, frames, etc. You had to put your own exhibitions up yourself. It had to be done cheaply." (Hedges 2010)

${ }^{9}$ Located in 8 Great Newport Street, Central London.
} 
Williams and Andrew Sproxton, encouraged an emerging generation by staging exhibitions in the Northern city. ${ }^{10}$ A third space, Southampton's Photographic Gallery, appeared around the same time as Half Moon Gallery. In 1977, Amber, a collective of documentary photographers and filmmakers opened Side Gallery in Newcastle with similar objectives to Half Moon Gallery. ${ }^{11}$ In the same year, Open Eye Gallery in Liverpool and Stills Gallery in Edinburgh were created, adding to the slowly growing group of independent photographic galleries in the UK.

Ron McCormick, Paul Trevor, Mike Goldwater took over the direction successively when Ewald went back to the US in 1973. Together with supportive photographer friends (such as George Solomonides), they were determined to support young photographers' work and to create opportunities for debates on contemporary professional practice. Half Moon Gallery became a limited company on March $10^{\text {th }} 1975$, aiming "to promote, maintain, improve and advance education, particularly by the staging of exhibitions and the encouragement of the art of photography". ${ }^{12}$ The gallery joined the growing web of cultural spaces born of grassroots initiatives in the vibrant East End, far from the cultural Establishment of central London. ${ }^{13}$ The history of radical struggle and the multicultural mix of Bethnal Green inspired early exhibitions. ${ }^{14}$ Its position on the periphery of the capital's cultural networks enabled "this tiny

\footnotetext{
${ }^{10}$ Martin Parr's first exhibition was shown at Impressions Gallery.

${ }^{11}$ Amber Associates, a collective committed to the documentary representation of working-class culture in the North, founded in London in 1969, established itself in Newcastle in 1970 (Konttinen 2002; Newbury 2002). Ron McCormick, active as director of Half Moon Gallery, was the first director of Side Gallery.

${ }^{12}$ Memorandum of Association, Half Moon Gallery Ltd, 10 May 1975, signed by Michael Goldwater, George Solomonides, Guy Ryecard, Shirley Read, Paul Trevor, Peter Johnson, and Neil Gulliver. Goldwater was named director. Arts Council archives.

${ }^{13}$ Among these initiatives were the E1 Festival, running in Tower Hamlets in the early 1970s. It evolved into the Tower Hamlets Arts Project, a community arts organization including film, photo, murals, and theatre workshops. Centreprise, the only independent bookshop in Hackney, was another community project created in 1971. (Amphoux 1973; Warpole 1977; Anderson 1991; Wetherell, 2013)

${ }^{14}$ Exhibitions such as "Festival, a picture story of the E.1 community festival" by Ron McCormick; "Estate", by Mike Goldwater and Pete Johnson, both c. 1974; "Bethnal Green 1949-1952; Photographs by Nigel Henderson"; "Brick Lane 1978; Photographs by Paul Trevor", both in 1978.
} 
little place in a backstreet in the East End of London" (Goldwater 2017) to experiment with more innovative and freeform gallery practices. It developed an independent identity characterized by an ethos of collective participation and a pragmatic desire to make photography more visible by supporting new projects. "Photography was our drug of choice!", Ed Barber confesses. ${ }^{15}$ The project was a magnet for people interested in contemporary photographic work and supportive of a space dedicated to engaging people in the appreciation, discovery and practice of photography.

The gallery appeared in a context of newly available funds for photography. The Arts Council began to support photographic exhibitions from 1967, when its new Royal Charter added photography to the Council's scope of intervention. Photography Officer Barry Lane was in charge of the photography sub-committee, which became a full Committee from 1973. This meant that exhibitions and photography projects by individual photographers could be supported through grants or awards (Picton 1977). These new funds, though limited, were sufficient to start off photographic projects, and a significant parameter in the emergence of initiatives for photography on the periphery of established art galleries. ${ }^{16}$ Half Moon Gallery's first grant covered $£ 500$ for running costs (1973/4), rising to $£ 2,020$ in 1975/6 (Picton 1977). Other sources of finance were the Greater London Arts Association (part of the emergent national network of Regional Arts Associations), Tower Hamlets Arts Council and the Greater London Council (between 1981 and 1986). Yet this should not be overestimated. Financial help from the Arts Council was always conditional on the organization's ability to raise its own money, which it demonstrated by organizing jumble sales and print auctions.

\footnotetext{
${ }^{15}$ Photographer Ed Barber joined the organization in Summer 1976, to help out with bookkeeping at first, before taking responsibility for the touring exhibitions. (Barber 2016)

16 Barry Lane was very supportive: "There are, at the moment, only four photography galleries in the country and the Photography Committee places the highest priority on their survival and success since they are likely to be crucial to the future development of the medium." Document signed by Barry Lane, "Photography estimates 1976-77”, Arts Council Archives.
} 
Renowned photographers Bill Brandt, David Bailey or Brian Duffy showed their support by contributing prints, while photographic studios donated material. Jumble sales were festive occasions as well as a vital means to keep the gallery's finances afloat (figure 3). Budgets were always on a shoe-string and Half Moon relied on its many volunteers, which it seemed to constantly attract. Its mailing sessions were social events in themselves. ${ }^{17}$

Money was always tight. The whole place ran on energy and enthusiasm. Everybody gave their time generously. No one was ever involved in a project like this to make any money. [...] The project was subsidized heavily by people giving time and energy as well as sharing their personal resources (Barber 2016)

In 1975, one series of events contributed to put Half Moon Gallery on the map. Alongside its regular exhibitions, a successful seminar series entitled "Camera Obscured?" unfolded between January and July. These monthly public discussions addressed "the current state of British photography by examining the ways that photography is used in our society and highlighting the conflicts of interest that arise " (figure 4). ${ }^{18}$ The themes discussed were "Young British Photographers", "Photography on the curriculum", "The task of the photojournalist", "Women in photography", "The dream sellers" (on commercial, fashion and editorial photography), and finally “The public face of British photography” (on issues related to publishing and exhibiting photography). Guest speakers were practicing photographers, curators, critics, picture editors, gallery administrators, educators, or the Arts Council's newly appointed Photography Officer, Barry Lane. ${ }^{19}$ By engaging with different actors from the

\footnotetext{
17 "A measure of [the organization's] relevance was that there were people clamoring to be involved. It was inspiring people.” (Goldwater 2017)

${ }^{18}$ Poster advertising the first seminar, Camerawork archive at Four Corners.

${ }^{19}$ Each discussion was recorded on tape and video and closely associated with an exhibition. Critic Ainslie Ellis praised the exhibition "Men" by women photographers which accompanied the fourth seminar: "this is clearly the best exhibition related to a theme, to a common purpose, that I have seen to date". (Ellis 1975)
} 
"worlds of photography"20, the seminars demonstrated Half Moon Gallery's understanding of photography as a visual discourse intervening in various ideological and social contexts. At a time when specialized magazine Creative Camera's editorial policy was driven by the ambition to see photography recognized as a fine $\operatorname{art}^{21}$, Half Moon Gallery found another role in asking provocative questions about the politics of photographic practices and their inscription in ideologically constructed regimes of representation.

One measure of the success of these seminars lies in the connections it made possible. Tom Picton, a lecturer in photography at the Royal College of Art, first met the members in that context and was offered to chair the last session (Goldwater, 2017). He became a very committed member of the project in the following five years. Jo Spence and Terry Dennett also made contact with Half Moon during the seminars. In May 1975, they had formed the Photography Workshop in Islington, "an independent educational, research, publishing and resource project" designed to examine historical and contemporary uses of photography (Bezencenet et Corrigan 1986). Spence and Dennett developed a critical stance regarding contemporary photographic practices, particularly the professionalization of the sector and its absorption in a competitive market. To them, these evolutions undermined alternative conceptions of the medium, with historical roots in the Labor movement of the 1930s, in which the "amateur", or non-professional photographer could act as an agent of democratic change: "The workshop grew of our dissatisfaction with current trends in British photography and our desire to contribute, as photographers, to social change”. (Photography Workshop 1975). They saw a need to “demystify" photography, as object, practice and social discourse,

\footnotetext{
${ }^{20}$ In reference to sociologist Howard Becker's “worlds of art”. (Becker 1984)

${ }^{21}$ Creative Camera, edited by Colin Osman and Bill Jay (1965-1969) then Colin Osman and Peter Turner, published the work of international photographers with images printed on entire pages, with little or no text. After a series of financial crises for the publication in the early 1980, a grant was negotiated with the Arts Council and the magazine was relaunched with more space given over to academic work. (Osman 1986) Colin was the owner of the magazine. (Brittain 1999)
} 
that is, to break the association of photography with an expert and exclusive form of knowledge, to resist its absorption in fine arts spheres, and to preserve it as a technology accessible to all. Spence and Dennett were both committed to uncovering the history of the British Workers' Film and Photography movement of the 1930s and sought to inspire contemporary practices through the use of photography as a radical tool for the expression and emancipation of minority voices (Edwards 2017, Ribalta 2015). These positions found an echo with members of Half Moon Gallery, who recognized common aims in the necessity to democratize photographic skills and give photography a role in activism. At the time, the radical approach defended by Spence and Dennett, expressed in particular in their misgivings about the professionalization of photography and in their commitment to a genuinely collaborative workshop model, were probably simply acknowledged and accepted, rather than fully embraced by members of Half Moon Gallery, as will be shown later. The two organizations decided to combine their energies and enthusiasm and the Half Moon Photography was formed in October $1975 .^{22}$ The program developed by the group was inspiring and ambitious. "We were embarking on a significantly bigger project than the gallery had been". (Goldwater 2017)

\section{The politics of the Half Moon Photography Workshop}

The project sustaining the Half Moon Photography Workshop (HMPW) was bold, and grounded in the recognition of common aims: to generate critical perspectives on documentary photography, to support politically conscious photographic practices, to expand the modes of access to photography across different social arenas, often outside of cultural

\footnotetext{
22 "The Half Moon Gallery has recently amalgamated with Photography Workshop and from this has now emerged Half Moon Photography Workshop. [...] Our programme will include a new gallery, bookshop, public darkroom and workshop space, where we will continue with a new programme of seminars, plus education workshops and community photography”. (Half Moon Photography Workshop 1975)
} 
institutions. HMPW played a central role in what Ribalta identifies as "the shift towards a new politicization of the debate on photographic documentary as a key discursive space" in the Western world in the 1970s. (Ribalta 2015)

The project revolved around three main activities. HMPW was to count a gallery showing regular exhibitions available for touring; a publication, Camerawork, conceived as a forum for debate on photographic practices involving a critical reflection on the politics of representation; and an information and resources project which hinged around educational workshops, darkrooms opened to all and technical and practical advice on using photography in the context of community politics. This third aspect was clearly influenced by Spence and Dennett. Their interest in alternative histories of photography and its uses in grass-roots activism as well as their experience in photography-based educational practices gave coherence to that side of the project and informed the notion of community photography. ${ }^{23}$ Bethnal Green, with its socially and ethnically mixed population would be a testing ground for uses of photography as a tool of empowerment. The "People's Gallery" was marked out as a space in the activities of the organization for the presentation of photographs produced in the community by local residents.

All three spheres of action (gallery, publication, resources) were complementary means of reaching to different audiences on local, national and international levels. ${ }^{24}$ "Establishing a photographic center with workshop, darkrooms and gallery in a place like Bethnal Green at that time was a radical act in itself." (Barber) Engaging with the fundamental question of how to "re-invent documentary" (Ribalta) as a critical discursive space was another.

\footnotetext{
23 "The Half Moon Workshop (sic) would be an umbrella for a variety of activities, of which Photography Workshop would form a major community-based part”, Letter from Mike Goldwater to Barry Lane, 15 September 1975, Arts Council archives.

24 "The idea behind this publication is that we can reach a wider audience than the gallery, seminars and workshops alone. [...] Camerawork is not a separate vehicle from the Half Moon Photography Workshop but an integral part of all our activities and at all times reflects and publishes our policies and aims." Half Moon Photography Workshop, “General Policy Statement”, 23 July 1976, Arts Council Archive.
} 
HMPW's radical approach, defined in its "Statement of Aims" 25 , published in issue 1 of Camerawork (figure 5), was structured by the overarching objective of placing photographic images and technology at the center of processes of social change:

By exploring the application, scope and content of photography, we intend to demystify the process. We see this as part of the struggle to learn, to describe and to share experiences and so contribute to the process by which we grow in capacity and power to control our own lives. (Half Moon Photography Workshop 1976) ${ }^{26}$ HMPW's position was political insofar as it considered photography, in the versatility of its social uses, as a discourse always already caught in ideological determinations and having political effects. To "demystify" photographic practices pointed to the need to deflate the pretensions of photography to be considered as an expert knowledge, thus precluding lay persons from using it for their own purposes. It was a call for a visual education which could arm the viewer critically in their reception of photographic images, and for practitioners "to explore [their] own motivations for taking pictures and the implication of their ultimate use". (Id)

This position distanced HMPW from discussions on the aesthetic merits of the medium which could be found in the pages of Creative Camera at the time, and announced that "the running of HMPW [would] reflect our central concern in photography, which is not 'Is it art?' but "Who is it for?'" (Half Moon Photography Workshop 1976) The organization was not concerned with modernist debates on the definition of an alleged essence of photography. Rather, it sought to examine the plurality of photographic practices in light of their involvement in diverse social and cultural contexts.

\footnotetext{
${ }^{25}$ HMPW's statement of aims incorporated many of the aims identified by Spence and Dennett in their own statement drawn up sometime around the date of the merger. Photography Workshop, "Statement of Aims", c. November 1975. Jo Spence Memorial Archive.

${ }^{26}$ These lines became Camerawork's masthead in the first nineteen issues.
} 
The endeavor echoed the intellectual debates of "the new art history", which questioned the social and material contexts of artistic production (Clark 1973; Cork 1979; Rees et Borzello 1986). It substantiated the theoretical framework developed in the emerging field of Cultural Studies, which posited the necessity for a critical theory of cultural practices, productions and institutions. Equally, HMPW shared perspectives with the objectives of the History Workshop, whose first editorial, published in the History Workshop Journal (a couple of months after the first issue of Camerawork) stated its dedication to:

making history a more democratic activity and a more urgent concern. We believe that history is a source of inspiration and understanding, $[\ldots]$ that history should become common property, capable of shaping people's understanding of themselves and the society in which they live. (History Workshop Journal Editorial Collective 1976)

Substituting the term "photography" to "history" in this quotation, one would recognize HMPW's objective to contribute to making photography a democratic tool of expression conducive to the sharing of knowledge and processes of social change. ${ }^{27}$

HMPW functioned from 1975 in a collective spirit. ${ }^{28}$ The many organizational tasks were shared among members on a voluntary basis, whereas the specific areas of publication and exhibition were organized through committees. Mike Goldwater, as director, and Jo Spence as coordinator were the only two paid members of staff at the beginning. Besides secretarial work, Spence was particularly involved in the publishing committee and the setting up of

\footnotetext{
${ }^{27}$ As Edwards underlines, in 1979 Spence was personally involved with the History Workshop's Art and Society group in organising a seminar on documentary practices in the UK and the US in the 1930s and 1940s. (Edwards 2017). The common reference to the workshop model was not fortuitous but indicated preoccupations with collaborative modes of production and the sharing of skills and knowledge as levers in empowerment processes, be it through history writing or image-making.

${ }^{28} \mathrm{HMPW}$ was not a collective in the strict sense of a non-hierarchical organization functioning on collective decision-making, even though it sometimes employed the term in correspondence. It did emulate such an organizational form but legally remained a registered charity with a director. This question resurfaced in summer 1977 as is explained further on. In contrast, Amber Associates in Newcastle - founders of Side Gallery in 1977 -, and the Hackney Flashers, in Islington (1975-9), were clearly organised as collectives.
} 
seminars. Her feminist and socialist convictions, as well as her commitment - with Dennett to unearthing the history of radical photographic practices, nurtured her search for ways of making photography work for social change in the present. Combined with her keen interest in how photographic images worked in different social contexts, these perspectives shaped her practice and critical thinking on photography. (Spence 1986, 1995; Roberts 1992; Wilson 2015)

Spence's programmatic article entitled "The Politics of Photography”, (Camerawork, Issue 1) gave coherence to HMPW's agenda between 1975 and 1977. The article criticized standards and practices in the press industry, denouncing the sensationalist and de-politicizing tendencies in contemporary editorial photography (Figure 6). Spence called for photographic practices to be rooted in a commitment to challenging dominant representations, and encouraged photographers to question the power relations inherent in the act of taking pictures. The article was the first to address the subject of community photography - a sign of Spence's interest for the socially transformative potential of these educational uses of photography. These alternative practices were first experimented by photographer Paul Carter from 1974 at the Blackfriars Settlement in London and replicated in many guises in different community projects across the country (Arts Council of Great Britain 1975; Nigg et Wade 1980; Kelly 1984; Bezencenet et Corrigan 1986). Such initiatives consisted in making photography accessible in local projects or campaigns by teaching photographic skills and opening darkrooms in community centers. The ambition was for photography to be used as a tool to organize, agitate, or simply document local life in a bottom-up approach that was absent from mainstream photographic practices. Community photography practices hoped to lay bare the mechanisms of power inscribed in the dispositif of image-making and challenged conventional documentary photography by enabling non-professional practitioners to represent themselves photographically. HMPW's statement of aims reiterated its commitment 
to encouraging community photography and Camerawork regularly published articles on community photography practices initiated in the country. ${ }^{29}$

Besides supporting community photography projects, the politics of HMPW were reflected in its dedication to expanding photography's contexts of visibility through an audacious program of touring exhibitions, and a commitment to running an independent quality magazine, Camerawork. These two areas of activity will now be examined more closely.

\section{Exhibitions and Camerawork}

In summer 1976, HMPW obtained the use of larger premises in Half Moon Passage. This provided room for an extended gallery program. Alongside the main gallery, a "work-inprogress" space was opened as well as a "People's Picture Gallery". Hosted in the foyer in Alie Street the latter was "designed to research and present East End social and economic events to the public via contemporary and historical photographs, documents, reminiscences, family albums, etc" ${ }^{\prime 3}$. This exhibition space signaled a desire for HMPW to be a cultural organization rooted in the local community, linking the visual culture of the East End, contemporary and historical, to wider issues of representation on a wider national and international level.

\footnotetext{
${ }^{29}$ See Paul Carter, "Doing Photography", Camerawork, 2, April-May 1976, p. 5; Jo Spence and David Hoffman, "Thoughts on THAP”, Camerawork. 5, February 1977, p. 10-11; Camerawork, March 1979, 13 special issue on community photography; Philip Wolmuth, "Photography in Opposition", Camerawork, 18, March 1980, p. 12. Interest in alternative technologies used in community photography practices were regular features too. See Terry Dennett, "Alternative Technology", Camerawork, 1, February 1976. p. 2.; Terry Dennett, "We also use Film to Take Pictures", Camerawork 3, July 1976. p. 10; Terry Dennett, "Print that Neg”, Camerawork, 5, February 1977. pp. 6-7; Steve Hoare, "Pinholing: From here to infinity", Camerawork, 6, April 1977, p. 4; David Hoffman, "Portable Darkroom", Camerawork, 13, p. 11.

${ }^{30}$ HMPW, "The role of the gallery within the workshop", internal document, July 1976, Arts Council Archives.
} 
The program of exhibitions in these different spaces were at all times closely connected to a program of seminars and to the contents of Camerawork. The new exhibitions were added to a catalogue of touring shows which travelled the country in the budding network of galleries. Yet the innovation introduced by HMPW was to circulate its shows to non-conventional spaces alongside more classical venues: schools, trade union halls, launderettes, pubs, churches, community centers... What made this possible was the technological process of lamination: instead of being placed in heavy and fragile glass-frames, photographs were "laminated", that is, laid out on cardboard panels covered with adhesive plastic sheets. This facilitated transport immensely and drastically reduced costs, since panels could be sent in a box by the post or on a train journey and received on the day. Exhibition panels were easy to make and extremely versatile in terms of layout and editing. They could combine text and image in a meaningful sequence, tell a story, explore a theme in depth, or include visual elements other than photographs. Being waterproof, the panels could be hung in open air areas. The process therefore enabled the exploration of new settings for photographic images and was copied by many other photography collectives looking for practical and cheap ways of creating exhibitions: ${ }^{31}$

[Half Moon Photography Workshop] was the model. They had established the possibility of having a gallery with exhibitions exploring specific themes. The lamination system was fantastic. [...] It was a liberating thing. You could send [photographic exhibitions] to the world. (Dewdney 2000)

The "Do-It-Yourself" dimension at the core of HMPW's touring exhibition program was a practical as much as a political choice, serving the objective of making photography accessible to non-gallery-going audiences. It signaled an interest not for the precious, rarefied photograph as art-object but rather for the intervention of photographic images, in exhibition

\footnotetext{
${ }^{31}$ The feminist collective the Hackney Flashers, of which Jo Spence was a key member, used lamination for their exhibition Women and Work (1975) and Who's Holding the Baby (1979). Andrew Dewdney and Neil Martinson at Cockpit Arts (London) also employed the technique for their projects with young people.
} 
form, in arenas outside of the elitist spheres of art. Ed Barber, in charge of this side of HMPW's activities between 1976 and 1980, reflected that "those touring shows travelled all over the UK, they were hung in lots of different types of spaces and seen by thousands of people - many of whom [would] have had very limited experience of looking at photographic exhibitions.” (Barber 2016). HMPW's unconventional approach to displaying photographs outside of the hallowed spheres of art represented a challenge to the sacralization of the work of art as necessarily unique, precious and auratic, a notion which, according to Benjamin in his critique of the bourgeois work of art, photography jeopardized (Benjamin 1935). Such a move on the part of HMPW belonged to a project to reclaim photography for social change by demystifying notions of preciousness or high technicality. Whether exhibited at the gallery or as travelling shows, in the early years the exhibitions stroke a balance between images in a documentary tradition and highlights on alternative practices. They raised fundamental questions on the documentary representation of socially marginalized groups (because of class, gender, ethnicity or age) and interrogated the position of the photographer in the creation of authentic, respectful and empowering images. ${ }^{32}$

Whether on-site or travelling, these exhibitions promoted the work of emerging or more established photographers, whose work exemplified this quest for renewed documentary approaches, which combined a research on form and the definition of an ethical position for the photographer. ${ }^{33}$ Typical themes - signaling HMPW's anchorage in a left-wing

\footnotetext{
32 The catalogue of touring exhibitions in May 1976 included for example: "Doing Photography, the work of the Young Photography Group in Blackfriars", "Cathal Road Estate" by Gregory Hale, "Tees-Side Industrial communities" by Derek Smith, "Kids show: photos by kids", "Men photographed by women" by a group of women including Sally Greenhill, Maggie Murray, Val Wilmer, "Women who are we?" by Claire Schwob, and "The Orkney Islands" by Chick Chalmers.

${ }^{33}$ The list of photographers who exhibited at HMPW is too long to enumerate. Yet the names of Mike Abrahams, Nigel Dickinson, Sally Greenhill, Angela Kelly, Peter Kennard, Daniel Meadows, Martin Parr, Claire Schwob, Chris Steele-Perkins or Paul Trevor for example, indicate an emerging generation of documentary photographers and photojournalists committed to producing work on social and political evolutions in 1970s and 1980s Britain.
} 
documentary tradition - ranged from factory work, farming, Northern Ireland, international political crises, youth subcultures, schooling, life in specific communities and multiculturalism, to campaigns against nuclear weapons or the Miners'strike.

HMPW's exhibitions available for loan were advertised in the pages of Camerawork, which also ran articles about the photographers or themes addressed in the shows. The publication of the magazine, arguably the more tangible legacy of HMPW today, was considered as a flagship of the collective's views in the wider national and international spheres. The magazine borrowed the distinctive format of a broadsheet and could be unfolded from an A4 to an A2 size. Its quality of printing - let to Expression Printers which was already responsible for the gallery's posters - was fair. ${ }^{34}$ The title typeface evoked a practical, unsophisticated visual identity, echoing the title's obvious reference to work and the workshop ethic, while covers made ample room to photographs. ${ }^{35}$ In its graphic style as much as in its contents, the magazine staunchly defended its editorial independence:

This magazine $[\ldots]$ may not be commercially profitable but the people at the Half Moon Photography Workshop who worked for nothing to get it out believe that the ideas, views and information it articulates are useful and worth their not inconsiderable efforts. [...] Self-publication represents a vehicle for information and work which would otherwise go unpublished. In so doing it challenges the prevailing ethic of our democratic society that anything can be said provided that you can afford to say it and that you can say it profitably. (Trevor 1977)

Camerawork was unique in the UK at the time in stimulating critical debates on the politics and ethics of photography and in envisioning image-making in relation to its contexts of

\footnotetext{
34 "Camerawork was not going to be a precious magazine, a gallery magazine, but an accessible magazine". (Goldwater 2011) The first issue had a run of 1,500 copies (sold out) and went up to about 5000 copies per issue. ${ }^{35}$ In contrast to Edward Steichen's Camera Work published in the US between 1903 and 1917. According to Mike Goldwater, the idea for the title came as the last minute: "it had to do with work, to give a practical feel to the magazine".(Goldwater 2011)
} 
production and use. It endeavored to address the politics of representation in relation, say, to class, children, women or the global South. ${ }^{36}$

While publishing photographs in the documentary tradition, it questioned the genre in crucial ways, both in its historical and contemporary forms. In the small world of British photography in the late 1970s, Camerawork acted as an essential forum for the exchange of ideas between photographers, art critics and theoreticians with an interest in photography. It published articles by theoreticians John Berger, John Tagg or Victor Burgin ${ }^{37}$, giving the magazine intellectual rigor, and made room for polemical tribunes which in turn led to heated discussions. For instance, Spence's interview with American photographer Robert Golden triggered an important debate. (Spence 1976) Golden's radical conception of documentary photography in the class struggle, his call for photographers to reflect on their class position and on the political determinations and effects of their images, pointed to the moral duty of the photographer. ${ }^{38}$ Golden's openly Marxist position was criticized in issue 4 of Camerawork by Roger Mayne, a photographer famous for his reportage images of Southam Street, London, in the 1950s. Mayne favored the view that photographers should seek to express personal views, and doubted that images could shift established social orders. The subject generated a spate of responses from Camerawork readers in the next four issues, mostly supportive of Golden. ${ }^{39}$ The controversy centered on the politics of documentary representation, the role of

\footnotetext{
${ }^{36}$ On this last issue, see "Smashing the Myth of the Noble Savage" by the Ifriqiyah Collective, Camerawork 4, Nov. 1976, p. 8-9; “The Photographer as Hero", Camerawork 7, July 1977 p. 10-11.

${ }^{37}$ Invited by Jo Spence to contribute his article "Art, Common Sense and Photography”, Camerawork, 3, July 1976, p1-2.

${ }^{38}$ Golden's series “Down the Road” was exhibited at HMPW in December 1976.

${ }^{39}$ Roger Mayne, “Letters”, Camerawork, 4, November 1976. p. 10; Roger Cox, “Letters”, Camerawork, 5, February 1977. p. 5; Larry Herman, “Letters”, Camerawork, 5, February 1977. p. 5; Roger Mayne, “An Unfashionable Opinion”, Camerawork, 6, April 1977, p. 11; Robert Golden, "Response to Roger Mayne”, Camerawork, 7, July 1977. p. 8.
} 
the photographer, and the efficacy of photography in social change. Thus, the magazine provided a platform for fundamental discussions on photography engaged in oppositional politics.

As members of the specific committee working on the production of Camerawork, Spence and Dennett were active in the debate, publishing their article "The unpolitical photograph?" in issue 7 as the controversy was drawing to a close. They refuted the alleged neutrality of the photographer, thus intervening in the critique of documentary representation and its aspirations to represent the "real" objectively:

We believe that photographers are already in politics. This is because the images we make carry ideological messages which, cumulatively, help to shape people's ideas, values and attitudes.(Spence et Dennett 1977)

Spence and Dennett's contribution to radical thinking on the politics of photography informed their practice and theoretical texts. ${ }^{40}$ Over the summer 1977 however, an internal crisis revealed tensions over ideological differences within the publishing committee. Spence was fired from the organization in August 1977 and from Issue 8 (November 1977), Dennett and herself were no longer credited as members of the editorial team.

The pair were always very radical in their critique of photographic institutions and practices, and particularly what they saw as a contemporary tendency for photography to be reclaimed by the refined bourgeois art world. They were very diffident about the professionalization of photography, which they believed threatened to remove a tool for democratic expression from the hands of non-professionals. They were relentlessly committed to developing a critical theory of photographic representation, at a time when few theoretical texts were written in

\footnotetext{
${ }^{40}$ For example, Spence and Dennett. "Photography, Ideology and Education", Screen Education, 21, Winter 1976-7; Spence, “What Do People Do all Day? Class and Gender in Images of Women”, Screen Education, 29, Winter 1978-9.
} 
Britain on the photographic image. Yet on all of these issues, the organization was evolving. Precisely at this time, HMPW was looking for larger premises to expand its activities. Some of its members were becoming more established in their careers. Also, Spence and Dennett's articles were considered by some as too heavily theoretical and distracting from image analysis per se.

A document kept by Dennett relates the terms of the industrial dispute which followed Spence's sacking, signed by Spence, Dennett, and Liz Heron. Sadly, it only offers one side of the conflict yet it is worthy of note. The letter makes the accusation that a "continued inference" by some members (Mike Goldwater, Tom Picton and Paul Trevor are named) "that any thought-out philosophies or viewpoints which were in any way progressive, feminist or Marxist [...] were automatically 'political', and not the concerns of photographers." (Photography Workshop 1977) This was a position that Spence and Dennett combatted. The crisis revealed fractures and misunderstandings within HMPW on its organizational structure, political stance and orientations. ${ }^{41}$ The contents of each issue had been the object of heated debates within the editorial committee, revealing a difficulty in reconciling different political positions and aims. The direction of HMPW seems to have wished for a less polemical tone within the pages of Camerawork, at a moment when the group was applying for more substantial subsidies from the Arts Council in order to acquire larger premises. Doubts subsist on whether the board of Half Moon Photography Workshop was desirous to cast a less oppositional image and tone down the editorial contents of the magazine. Also, the sacking was a bitter experience for Spence, who discovered that the organization was only

\footnotetext{
${ }^{41}$ The Photography Workshop argued that "the present dispute about the magazine revolve[d] primarily around questions of direction and content. That is to say the journal's ideological standpoint and editorial line".

(Photography Workshop 1977)
} 
nominally a collective, when Goldwater as formal director of the original limited company decided to end her contract.

Jo Spence, Terry Dennett, and Liz Heron (a volunteer at HMPW), went on with new projects with the Photography Workshop. ${ }^{42}$ Spence's feminist group The Hackney Flashers produced its second exhibition “Who's Holding the Baby”.(Arts Council of Great Britain 1979; Klorman-Eraqi 2017) With the compensation money obtained after the arbitration of the industrial tribunal, Spence and Dennett edited the volume Photography/Politics I which took up many of the issues opened in the first seven issues of Camerawork. ${ }^{43}$

The following issues of Camerawork, up until 1980, were themed issues, in an effort at editorial coherence: the media coverage of the confrontation between the National Front and anti-racist groups in Lewisham (issue 8), "the Picture Story" (issue 9) the history of Mass Observation (issue 11), portrait photography (issue 12), community photography (issue 13), or the coverage of the Troubles in Northern Ireland (issue 14). Each issue examined different aspects, visual and theoretical, of a photographic practice. The pages of the magazine devoted more space to photographs. The issue on Northern Ireland caused a stir and brought Camerawork under the radar of the Home Office. It was reported to Prime Minister Margaret Thatcher as a case of "biased reporting" against British troops in Northern Ireland, and as

\footnotetext{
${ }^{42}$ Half Moon Photography Workshop retained its name after the break-up, until spring 1981. (Read 2017)

43 "As co-founders of the Workshop and its magazine Camerawork we felt it crucial for us, as socialists, to call into question various institutional photographic practices, and to do everything possible to engage in the widest possible debate of the politics of visual imagery. Important also we felt was the urgent task of attempting to raise from obscurity, and re-examine, the earlier traditions of left wing photography, before they became elevated and rarefied as part of the bourgeois "documentary tradition" within various art establishments." (Dennett et Spence 1979)
} 
circulating "extreme”, "ultra-seditious" and "blatant Left-wing Republican propaganda" ${ }^{4}$ The Arts Council was quizzed over its financial support to HMPW, and Barry Lane had to intervene to reassure the government that HMPW was not a militant group supporting the Republican interest, and to assert that the Arts Council could not be held responsible for the views expressed in the self-published magazine. The controversy drew in sharp relief the question of independence and reliance on public funds of artistic organizations. This was another problem on which Spence and Dennett on the one hand, and the rest of HMPW on the other irreconcilably disagreed, the former calling for complete financial independence from public funds, while the latter considered public support indispensable to keep activities going and developing.

At the moment of the break-up with the Photography Workshop in summer 1977, HMPW announced that it would relocate to a new building on 119/121 Roman Road in Bethnal Green. ${ }^{45}$ The costs of refurbishment required considerable financial help from the Arts Council's Housing the Arts program, from the borough of Tower Hamlets as well as a lot of fundraising for HMPW. The new building would provide a larger gallery space, rooms for seminars, slide and print copying facilities, a communal and five individual darkrooms, open to all from a small membership fee (figure 7):

The concept was to be a center of photography, to have a gallery with regular exhibitions, to have a magazine, regular publications, darkrooms open to the public, workshops on image-making, to run projects on particular themes as they evolved, to run a photo-agency from the building so that people interested in photo could see how professional photographers operate. (Goldwater 2017)

\footnotetext{
${ }^{44}$ Letter to the Secretary of State for Northern Ireland from David Bryce, Grand Secretary at the Grand Lodge of Scotland, 26 September 1979, Letter to the Prime Minister from Mr L.T. Coton, 18 September 1979. Arts Council Archives. Enoch Powell was reported to have been infuriated by the issue.

45 “HMPW Appeal fund”, Camerawork, 7, July 1977. "For the first time we will be able to cover many different aspects of photography under one roof, putting our ideas and theory into practice."
} 
The touring exhibitions and the publication of Camerawork continued actively while the building was being redone. ${ }^{46}$ Yet another turn in the history of HMPW was the departure of director Mike Goldwater and exhibition officer Ed Barber in 1980. Changes of course in structure and orientation were once again the main factors.

\section{Camerawork into the 1980s}

From Half Moon Gallery to Half Moon Photography Workshop and finally to Camerawork (the name of the gallery was aligned on that of the magazine from spring 1981), the evolution of the organization in the late 1970s and 1980s was subject to changes in cultural policy on a national level while also influenced by processes at work in the cultural sector in Britain. Cuts in public spending implemented by the conservative government had a direct impact on the Arts Council and the grants it could allocate to its recipients. Its budget was not revised to take inflation into account while the government favored incentives for business investment in the arts to make up for the loss. In 1980s, the Photography Committee of the Arts Council was axed, and merged in the Visual Arts Panel. This meant that applications for photography projects would no longer be assessed by specialists but by a multi-disciplinary panel, while money was to be shared among more recipients.

Evolutions in the cultural sector also affected the organization. Whereas Half Moon Gallery had started as a grassroots initiative led by practicing photographers who were passionate about promoting photographic practices, by the turn of the decade HMPW's growth and greater dependence on Arts Council revenue funding meant that its concerns were of a more administrative sort. The balance between arts administrators (a sector undergoing fast

\footnotetext{
${ }^{46}$ In the end it was over three years overdue, mostly because of conflicts with the borough of Tower Hamlets over liabilities.
} 
professionalization) and photographers shifted as the number of staff increased in the $1980 \mathrm{~s}^{47}$ Under its new director Shirley Read, Camerawork continued to produce and tour exhibitions, albeit in adverse conditions because of the delays in refurbishing the new space. ${ }^{48}$ It started making links with the neighbor organization Four Corners Films, setting up joint events on Roman Road. ${ }^{49}$

Yet the organization was mired by a lack of continuity in terms of staff and contributors. The editorial team and direction of the magazine changed several times between 1980 and 1985 when the last issue was produced (Issue 32, summer 19985) ${ }^{50}$. Camerawork's annual reports in the 1980 s point to a recurrent difficulty in finding its coherence. ${ }^{51}$ A management committee was set up in 1982 in an attempt to resolve structural problems. The Arts Council called again for an assessment in 1984. It was decided to continue supporting for the gallery, the darkroom activities and the magazine. Camerawork announced in the new masthead (issue 20, September 1980) that it would be "a forum for analysis, critique, theory and information in order to provide the basis for using photography within socialist and feminist practices". The endorsement of socialist and feminist positions can be read as a reaction to the election of a Conservative government in May 1979 which cast artistic organizations in a position of

\footnotetext{
47 "We had a maximum of eleven people at one time in the 1980s but more usually it was around six or eight." $(\operatorname{Read} 2017)$

48 "The delays have produced appalling working conditions [...] resulting in low staff morale, and making it virtually impossible to plan our future program or finances". Camerawork, "Report on the year 1981-2, Plans for the year 1982-3", June 1982, Arts Council Archives

${ }^{49}$ Id. Four Corners Films is still in existence in 2017 and occupies the building on 120 Roman Road that Half Moon Photography Workshop/Camerawork had secured. It was agreed at the turn of the 1980s with the Arts Council that Four Corners Films would obtain the use of the building when Camerawork closed. This explains why they are today in possession of part of Half Moon Photography Workshop/Camerawork's archive.

${ }^{50}$ Shirley Read and Greg Khan were co-ordinators for issues 8-22 (November 1978 to summer 1981) (Read 2017) Kathy Myers was appointed Editor in September 1983 and Liz Wells held this capacity for the last issues.

${ }^{51}$ Stevie Bezencenet, who sat on the photography committee of the Arts Council, wrote about the confused “internal ideology of the organization". $1^{\text {st }}$ august 1984, correspondence with Barry Lane Arts Council Archives.
} 
opposition and resistance. Yet the new political climate, celebrating individualism under the banner of a neoliberal breed of conservatism, considerably undermined the British Left.

In that political configuration, Camerawork was kept afloat financially by the support of the Greater London Council, led by Labour radical Ken Livingstone. ${ }^{52}$ Between 1981 and 1986, Livingstone's cultural and social policies for Greater London were openly supportive of hundreds of progressive organizations working in the cultural and social fields to promote minorities' rights, representation and cultural expression. It resisted the policies of cuts in the public sector, a pillar of the Thatcherite program. When the government eventually abolished the GLC in 1986, many organizations directly supported by it floundered. Camerawork was no exception and suffered from the constriction of subsidies from all sources. The resignation of Carl Gardner, the last co-ordinator at Camerawork, and the end of the magazine, in debt, was announced in the annual report of 1985-6. The publication had stopped between issue 30 and 32 (spring 1984 and spring 1985), and its readership had dropped by 75\% went it was relaunched. (Camerawork 1985)

The organization was therefore deeply affected by the turning of the tide in cultural policies in Britain. It kept on trying to adapt and find its orientation in these hostile conditions. The fact that no member from the original group remained active in the project in the early 1980s goes some way to explain the loss of a clear orientation or agenda. Another influential publication, the photographic magazine Ten.8, launched in Birmingham in 1979 by Derek Bishton, Brian Homer and John Reardon, although not a rival, attracted readers that Camerawork was no longer in a capacity to keep. In many ways, Ten. 8 carried on the important task initiated by Camerawork of generating critical debates on photographic representation and the politics of

\footnotetext{
${ }^{52}$ Camerawork received $£ 40,000$ from the GLC for the year 1984-5. Annual report 1985-6, Arts Council Archives.
} 
the documentary gaze in particular. Benefiting from the growth of photography courses in Higher Education, Ten. 8 was more successful than Camerawork in taking on board a critical agenda which interrogated photography and identity politics through the prisms of feminist and post-colonial critique.

That there was space for such a role when Camerawork eventually disappeared is in itself evidence of its pioneering role in that field and the necessity of such debates. In disseminating a radical history of documentary practice, it had prepared the ground for the kind of theoretical discussions that Ten. 8 was able to generate through the $1980 \mathrm{~s}$.

\section{Conclusion}

The details of Half Moon Photography Workshop's history and of the political tensions which shaped but also eventually fractured it are extremely important in order to understand, in an archeological way, how the British photographic milieu was structured in the 1970s. From the margins of the art world, the HMPW opened an essential space for the critical discussion of photography's role in society and its uses in practices enabling social change. In this defining decade, the organization contributed to the recognition of photography not only as an art form but a vital form of expression inscribed in a diversity of cultural practices. The political orientations that HMPW defined, in the particular context of the institutionalization of photography, of oppositional politics and the development of grassroots cultural organizations were of paramount importance. HMPW had extremely ambitious aims and the very debates which caused tensions and divisions among its members in the longer term were nevertheless crucial. The development of critical perspectives and theoretical texts on the politics of the photographic image, on its contextual and ideological determinations, on its audiences and political effects, came in a context when very little was written on the subject. Visual studies were in their infancy. In that pivotal period, HMPW became a catalyst for energies, ideas and 
innovations in photographic practices which enriched the landscape of British photography. It produced extremely pertinent insights into social documentary, the myth of objectivity, and the search for the authentic, empowering image. It created the conditions and spaces for piercing critical exchanges on photography and, importantly, made people meet and start off their own projects. HMPW and its influential magazine, which extended the reach of the gallery and continued the debates the organization had in its local community, were a reference for many other photographic organizations which appeared in its wake. The availability of its archival material at the Photography and the Archive Research Centre (London) and at Four Corners Films, who today use the gallery's former premises on Roman Road, must be the starting point for a renewed investigation in the fundamental role played by this little organization in the East End of London.

\section{Bibliography}

Anderson, Douglas. "Bums on Seats: Parties, Art and Politics in London's East End". TDR (1988-), Vol. 35, 1 (Spring, 1991), pp. 43-59.

Amphoux, Nancy. 1973. What is Centerprise? London: Centerprise.

Arts Council of Great Britain. 1975. British Image 1. London: Arts Council of Great Britain. - 1979. Three Perspectives on Photography: Recent British Photography. London: Arts Council of Great Britain.

Barber, Ed. 2016. Interview with the author, June.

Becker, Howard. 1984. Art worlds. Berkeley: University of California Press.

Benjamin, Walter. 1935. The Work of Art in the Age of Mechanical Reproduction. Translation J. A Underwood. London: Penguin.

Bezencenet, Stevie, et Philip Corrigan. 1986. Photographic Practices: Towards a Different Image. London: Comedia.

Brittain, David. 1999. Creative Camera: Thirty Years of Writing. Manchester and New York: Manchester University Press.

Camerawork. 1985. "Annual Report 1984-5". Arts Council Archive.

Clark, Timothy. 1973. Image of the People: Gustave Courbet and the 1848 Revolution. London: Thames \& Hudson.

Cork, Richard. 1979. The Social Role of Art: Essays in Criticism for a Newspaper Public. London: G. Fraser.

Dennett, Terry, et Jo Spence, Ed. 1979. Photography/Politics I. London: Comedia.

Dewdney, Andrew. 2000. Andrew Dewdney, interview with Shirley Read. British Library. Oral History of British Photography, National Sound Archive. 
Edwards, Steve. 2017. "The Fires Last Time: Documentary and Politics in 1970s Britain", FotoMuseum. [Online] https://www.fotomuseum.ch/en/explore/still-

searching/articles/153919_production_collectives_and_skill Accessed 28th November 2017.

Ellis, Ainslie. 1975. "On View". British Journal of Photography, May, 388.

Evans, Jessica, Ed. 1997. The Camerawork Essays: Context and Meaning in Photography. London: Rivers Oram Press.

Ewald, Wendy. 2006. Wendy Ewald interviewed by Shirley Read, C459/191. National Sound Archive. Oral History of British Photography.

Goldwater, Mike. 2011. Interview with the author, London

. 2017. Interview with the author, London.

Half Moon Photography Workshop. 1975. "Newsletter". Arts Council Archive.

- 1976. "Statement of Aims". Camerawork 1 (February): 8.

Hedges, Nick. 2010. Interview at his home.

History Workshop Journal Editorial Collective. 1976. "Editorial". The History Workshop Journal 1, 1: 1-3.

Jay, Bill. 2004. "Magazine Memoirs: Creative Camera and Album, 1968-1972, Conference ' Happened Here? Photography in Britain since 1968'." National Museum of Film, Photography and Television. Bradford.

Kelly, Owen. 1984. Community, Art and the state: Storming the citadel. London: Comedia Publishing.

Klorman-Eraqi, Na'ama. 2017. "The Hackney Flashers: Photography as a Socialist Feminist Endeavour". Photography and Culture 10 (1): 53-71.

Konttinen, Sirkka-Liisa. 2002. National Sound Archive. Oral History of British Photography. McWilliams, May. 2009. "The Historical Antecedents of Contemporary Photography Education: A British Case Study, 1966-79". Photographies 2/2: 237-54.

Newbury, Darren. 2002. "Documentary Practice and Working Class Culture: An Interview with Murray Martin (Amber Films and Side Photographic Gallery)". Visual Studies 17 (2): 113-28.

Nigg, Heinz; Graham Wade. 1980. Community Media: Community Communication in the UK: Video, Local TV, Film and Photography. Zurich: Regenbogen-Verlag.

Osman, Colin. 1986 "A Short History". Creative Camera, 253: 6.

Photography Workshop. 1975. "Untitled document". Jo Spence Memorial Archive. Photography Workshop. 1977. "A Statement on the Question of Camerawork". Oct.14th 1977. Internal Papers, Jo Spence Memorial Archive.

Picton, Tom. 1977. "If it's art, we can support it!" Camerawork, no 5 (February): 1-2. Read, Shirley. 2017. Shirley Read, personal conversation with the author, June.

Rees, A. L., et Frances Borzello, Ed. 1986. The New Art History. London: Camden Press. Ribalta, Jorge. 2015. Not Yet: On the Reinvention of Documentary and the Critique of Modernism : Essays and Documents (1972-1991). Madrid: Museo Nacional Centro de Arte Reina Sofía.

Roberts, John. 1992. Selected errors: Writings on Art and Politics, 1981-90. London: Pluto Press.

Spence, Jo. 1976. "Golden Rules OK? Interview of Robert Golden". Camerawork, $\mathrm{n}^{\circ} 3$ (juillet): 4.

1986. Putting Myself in the Picture: a Political, Personal and Photographic Autobiography. London: Camden.

. 1995. Cultural Sniping; The Art of Transgression. Ed. Jo Stanley. London: Routledge. 
Spence, Jo; Dennett, Terry. 1977. "The Unpolitical Photograph?" Camerawork, $\mathrm{n}^{\circ} 7$ (July): 67.

Trevor, Paul. 1977. « The Price of Self-Expression, an Article on Self-Publication ». Camerawork, $\mathrm{n}^{\circ} 1$ (February): 7.

Warpole, Ken. 1977. Local Publishing and Local Culture: An Account of the Centerprise Publishing Project 1972 - 1977. London: Centerprise Trust Ltd.

Wilson, Siona. 2015. Art Labor, Sex Politics: Feminist Effects in 1970s British art and Performance. Minneapolis: University of Minnesota Press.

Witherell, Sam. "Painting the Crisis: Community Arts and the Search for the 'Ordinary' in 1970s and '80s London" History Workshop Journal, Volume 76, Issue 1, 1 October 2013, Pages 235-249

Photographs reproduced with kind permission from Four Corners Archive. (C) Four Corners Archive / Half Moon Photography Workshop 